\title{
Ethnobotanical notes on a lesser known Gymnosperm family Taxaceae of Himalayan regions in India, adjoining countries and in South-East Asia
}

\author{
Sunita Bisht and Rita Singh ${ }^{1}$ \\ University School of Environment Management, Guru Gobind Singh Indraprastha University, Sector 16C, \\ Dwarka, Delhi-110078, India \\ E-mail IDs: sunitabisht137@gmail.com; rsinghipu@gmail.com \\ ${ }^{1}$ Communicating author
}

[Received 20.04.2020; Revised 19.06.2020; Accepted 26.06.2020; Published 30.06.2020]

\begin{abstract}
The study documents the diversity and the ethnobotanical knowledge of the gymnosperm family Taxaceae in Himalayan regions of India and adjoining countries and Southeast Asian countries. Data were collected and simulated from our study on Indian Himalayan region and from the published literature. Our study revealed that out of five genera of Taxaceae that occur naturally from Indian Himalayan region to South East Asian countries ethnobotanical uses of only Taxus is well documented as compared to other genera. It is suggested that Taxaceae and related ethnoecological knowledge resource are in urgent need of conservation. This may be done by strategically involving educated generation among local indigenous communities or fast paced depletion, transformation of natural habitats, migration of younger populations would eventually lead to gap in the transmission of situated knowledge and shall be lost forever.
\end{abstract}

Key words: Taxaceae, Distribution, Traditional Knowledge, Medicinal Uses, Gymnosperms

\section{INTRODUCTION}

Taxaceae is a small family yet one of the most important group of plants whose taxonomic position has been debated even today (Cheng et al. 2000; Hao et al. 2008; Ghimire \& Heo 2014). It includes six genera Amentotaxus, Austrotaxus, Cephalotaxus, Pseudotaxus, Taxus and Torreya and having around 30 species globally, which are distributed in moist and forested areas of the world (Price 1990, Simpson 2010). Except for Austrotaxus these taxa are distributed all along the Himalaya Hotspot including India (Kashmir, Himachal Pradesh, Uttarakhand, Sikkim, Northern parts of West Bengal, Assam, Meghalaya, Arunachal Pradesh, Manipur, Mizoram), Nepal, Bhutan, eastwards in China, Myanmar and other Southeast Asian countries which are parts of Indo-Burma, Philippines, Sundaland and Wallacea Hotspots. All these Hotspots have peculiar floral and faunal diversity along with unique biogeography (Mao et al. 2009; Singh et al. 2018; Ding et al. 2019). Indigenous communities living in these areas have easy access to the local flora. These plants are one of the most vital sources for the generation of livelihood and most importantly medicines (traditional as well as in modern-day systems) for native people. According to World Health Organization approximately $80 \%$ population of the developing countries depend on plants for health-related issues (WHO 2001; Azaizeh et al. 2003; Calixto 2005; Rai \& Lalramnghinglova 2010; Gao et al. 2019b). The indigenous people inhabiting in these Hotspots are the reservoir of ethnoecological knowledge which they have acquired over a very long period of time through hit - trial practices and shared experiences. It is a wellestablished fact that traditional ethnoecological knowledge (TEK) of tribal communities is highly influenced by their socio-cultural and historical background as well as the biogeography 
of the area (Cook \& Offit 2008; Zhasa et al. 2015; Badola 2017; Phumthum et al. 2018; Kahlon $\&$ Singh 2018). People from various background and with different needs utilize the natural floras in variety of ways for their survival (Zhasa et al. 2015; Gonçalves et al. 2016; Pieroni et al. 2017; Phumthum et al. 2018). Therefore, the existence and survival of forest and its resources mostly depend on the tribal communities as they are the one, who possess in-depth knowledge of local plants and have a deep bonding with forests and ethnoecology of closely knitted components of biodiversity around which their biocultural societies have evolved. The importance and need of traditional communities in protection and conservation of biodiversity has also been highlighted in the objective 5 of The Global Strategy for Plant Conservation: 2011-2020 (Convention on Biological Diversity 2012). The assessment of local indigenous knowledge can be used as a criteria for setting the conservation priorities (Dalle \& Potvin 2004). However, decreasing trends in transfer of existing traditional and ethnoecological knowledge to younger generations due to their urban or suburban migration for better earnings has resulted in a gap in the temporal use of these resources which will subsequently lead to the loss of huge knowledge resources (Kunwar \& Duwadee 2003; Tangjang et al. 2011). Traditionally ethnic knowledge is verbally transmitted among families and societies and is also gender specific. Insufficient documentation of ethnobotanical and ethnoecological information by local populations of indigenous communities and by academia acts as a catalyst in knowledge degradation. Many researchers from various countries have highlighted the need to study the diversity and documentation of ethnoecological uses of plants and overall biodiversity to address the future challenges (Bhardwaj \& Gakhar 2008; Rai \& Lalramnghinglova 2010; Poudel et al. 2013; Gao et al. 2019b).

The documentation and the assessment of ethnobotanical uses can also be utilized as a tool in measuring the sustainable usage of forests resources (Pei et al. 2009). Among gymnosperms, the members of Taxaceae have also been utilized in varied number of ethnic uses especially due to their medicinal properties. The phytochemical studies also enumerated their vast medicinal constituents (Koyama et al. 2006; Nisar et al. 2008; Saeed et al 2010). This study is an attempt to collect and collate a comprehensive data on ethnobotanical uses of the members of Taxaceae of the Indian Himalayan regions, adjoining countries and Southeast Asian countries based on the data prescribe the need for conservation of taxads in their natural habitats in these Hotspot regions.

\section{METHODOLOGY}

\section{Study area and data collection}

The members of Taxaceae are distributed throughout the Himalaya and South-East Asia between different elevational ranges. In the present study, published data were collected on countries which are adjacent to or in Himalayan region like India, Nepal, Bhutan, China and other SouthEast Asian countries like Myanmar, Vietnam, Laos, Thailand, Malaysia, Indonesia, and Philippines and henceforth mentioned as the study area. These areas have characteristic geographical and climatic features. The enormous variations in the topographical and geographical features of these areas provide a wide variety of habitat to plants and thus to secondary metabolites they produce.

A comprehensive data on ethnobotanical knowledge related to species of Taxaceae was collected based on scientific literature from books, journals, various scientific organizations websites, electronic databases (google scholar, researchgate, web of science, science direct) and visiting various libraries and Herbaria. The literature was collected using the keywords like traditional knowledge, ethnobotany, medicinal value, taxonomy, distribution, Himalaya, South East Asia. The information on ethnobotany was compiled from around 100 research papers 
and literature available till 2019. Also, field studies were conducted in the Indian Himalayan region during 2016 - 2019 to document the current distribution patterns and traditional knowledge on Indian Taxaceae. Online IUCN Red list was referred to find out the accepted number of species within Taxaceae.

\section{RESULTS}

Out of the six accepted genera of Taxaceae, five viz., Amentotaxus (5 spp.), Cephalotaxus (8 spp.), Pseudotaxus (1 spp.), Taxus (5 spp.) and Torreya (3 spp.) are naturally distributed in the hilly regions of the study area (Table 1) at different elevations ranging between $100 \mathrm{~m}$ (Yang et al. 2013a) - $3700 \mathrm{~m}$ a.m.s.l. (Thomas \& Farjon 2011) and are used by indigenous communities in various forms for day to day activities and livelihood since ages.

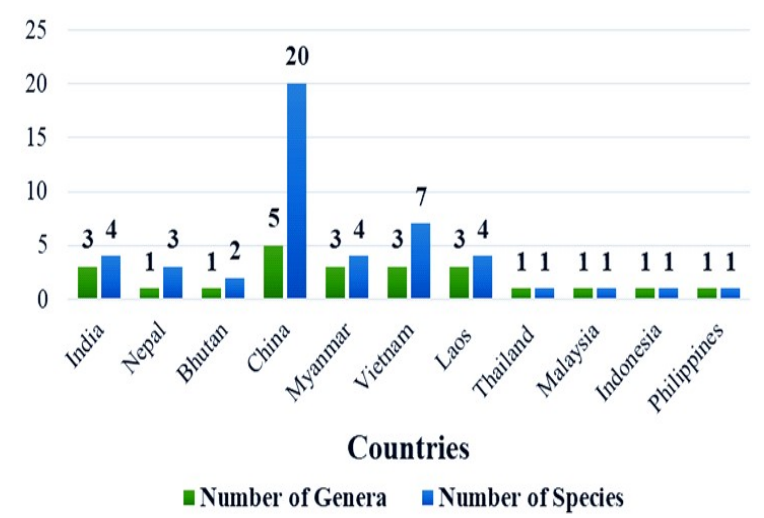

Figure 1. Distribution of species in the study area

Among Taxads, China harbours five out of six known genera and twenty species whereas Thailand (Cephalotaxus), Philippines (Taxus), Malaysia (Taxus) and Indonesia (Taxus) are least diverse in number of genera (1) and species (1). Vietnamese taxads are represented by Amentotaxus (3 spp.), Cephalotaxus (1 sp.) and Taxus (3 spp.), three genera and four species in India (Amentotaxus,1 sp.; Cephalotaxus, 1 sp. and Taxus, 2spp.), Laos (Amentotaxus, 2 spp.; Cephalotaxus, 1 sp. and Taxus, 1 sp.), Myanmar (Amentotaxus, 1 sp.; Cephalotaxus, 2 spp. and Taxus, 1 sp.) and one genus and three species in Nepal (Taxus, 3 spp.). Other than these the data also shows distribution of one genus and two species in Bhutan (Taxus, 2 spp.) (Figure 1). The Chinese, including Taiwanese, Taxaceae is represented by five genera Amentotaxus ( 3 spp.), Cephalotaxus (8 spp.), Pseudotaxus (1 sp.), Torreya (3 spp.) and Taxus (5 spp.). It is the only country in which out of the total documented species (recorded in literature) $91 \%$ species are naturally distributed.

\section{Ethnobotanical Uses}

Almost every species, except few, which are listed in Table 2 has some or the other ethnobotanical use in the form of traditional medicines, construction material, agricultural uses, for wood carving, etc. A total of 12 categories of ethnobotanical uses are identified from the published data and field surveys for Taxaceae (Figure 2).

Out of these identified categories, twelve species were found to be of medicinal importance and is used for treating various diseases and ailments in the form of paste, beverage or decoction. These species are basically used to treat cough, cold, fever, gastrointestinal problems, respiratory 


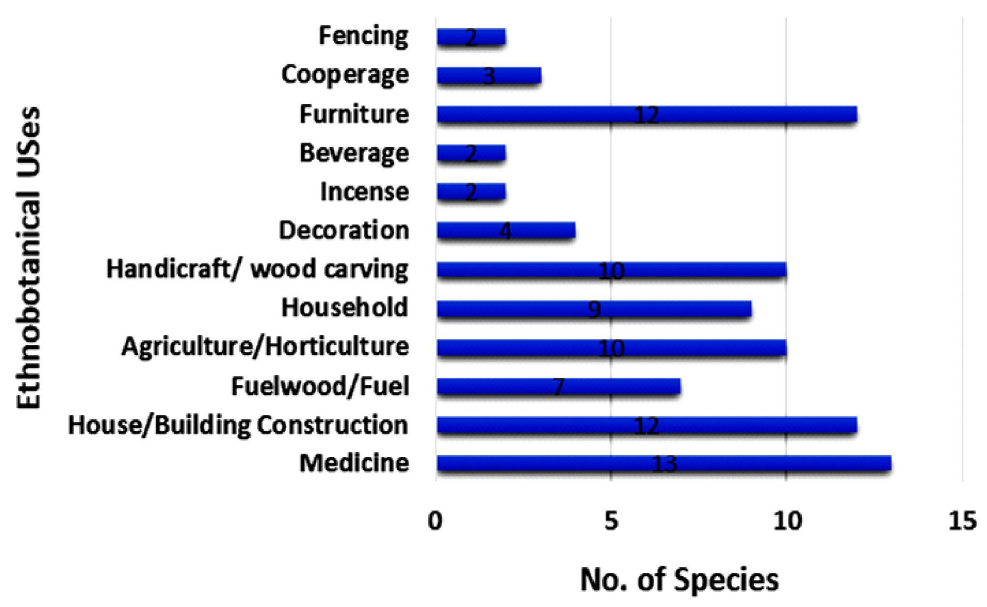

Figure 2. Various ethnobotanical uses of plants

problems, problems related to blood circulation, skeleton-muscular problems and most importantly for treating cancer (Figure 3). Gastrointestinal problems such as indigestion, gastritis, diarrhoea, jaundice, severe biliousness are traditionally treated with medicines prepared from these species by various methods in various forms in various places. Taxaceae members has beneficial role in treating asthmatic people, bronchitis, other respiratory disorders and infections. Apart from medicinal properties these are used as fuel in the form of lamp oil or firewood, for decoration purposes, as insecticidal and for animal bedding. Mostly these are used in construction of bridges, buildings and furniture due to strength and flexibility of their wood.

Genera-wise distribution of all the Taxaceae that occur in the study area are alphabetically arranged along with their ethnoecological uses below.

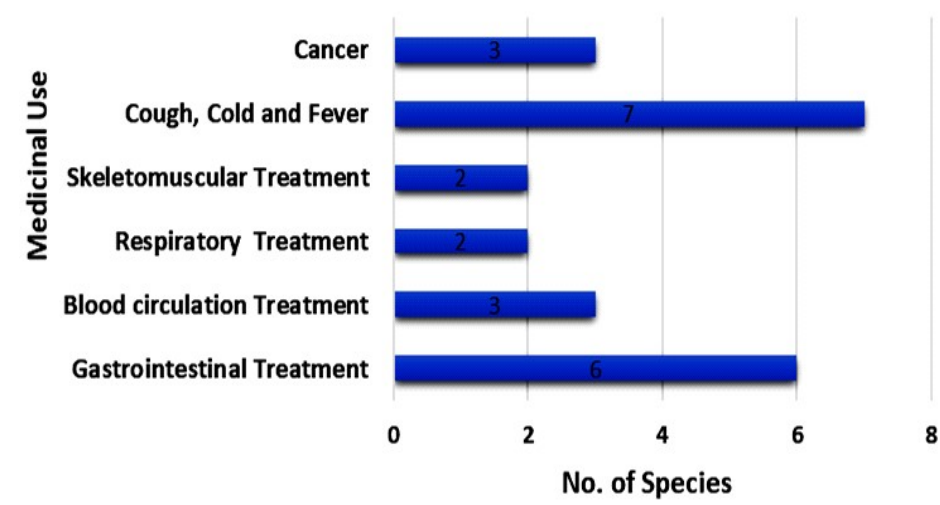

Figure 3. Medicinal uses of the species

Genus: Amentotaxus Pilg.

The genus Amentotaxus comprises of five species distributed mainly in Eastern Himalaya of India and in Southeast Asia. The species recorded in this study has restricted distribution and limited information regarding their ethnobotanical uses. Amentotaxus assamica that was first reported from India and later from Myanmar has not been researched much from ethnobotanical point of view. Only a few papers suggest their being used in house construction and as firewood. There is no specific record about the medicinal uses of this species by tribal or local communities. Similar is the case with Amentotaxus argotaenia and Amentotaxus poilanei. These species are used 
medicinally but is unclear for which particular ailments they are used. Not only these two species but all the documented species in this study have very limited information regarding their medicinal uses, one explanation could be the reluctance of sharing the secret recipe of traditional medicines by the indigenous medical practitioners. Researches are being undertaken considering the possibility of extracting anti-cancerous drug from species of Amentotaxus (HiltonTaylor et al. 2013b; Thomas et al. 2017).

Genus: Cephalotaxus Siebold et Zucc. ex Endl.

Cephalotaxus represents eight relic species distributed in India, China and Southeast Asia. The genus which is found to be more diverse is least studied and its ethnobotanical uses are also not well documented. Cephalotaxus mannii is the only species in which some work has been done but rest of the species still need to be studied. Medicinal information is scarce and inadequate for Cephalotaxus.

\section{Genus: Pseudotaxus W.C. Cheng}

The monotypic genus is represented by Pseudotaxus chienii, which is endemic to Southeastern region of China and is used as a carving material and for the preparation of utensils. Some more detailed study is required to find out other possible uses of the species.

\section{Genus: Taxus L.}

The genus is represented by five species in the study area out of the ten species found in the world (Farjon 2010). Among these Taxus wallichiana is widely distributed followed by Taxus mairei and Taxus contorta. Detailed ethnobotanical uses of Taxus wallichiana has been deeply studied and well documented in the countries of occurrence. It is found that this species is mostly used in treating various ailments by local inhabitants. India and Nepal have maximum recorded medicinal uses as compared to other countries. Taxus wallicbiana is also used as a source of wood for building construction and furniture making in countries like India, China, Nepal and Vietnam. Also, there are some peculiar uses of this species in few countries. In India it is applied by local Brahmins (religious community of people) as a red dot over forehead whereas in Nepal Taxus wallichiana and Taxus contorta are considered as a sacred tree. During field survey it was found that in Western Himalaya Taxus contorta is used to prepare a beverage (Jya) by Bhotiya community of Uttarakhand as it keeps the body warm during severe winter. Use of Taxus for furniture making, as a cooperage and construction material and for wood carving and turning are some of the other traditional uses reported from the study area.

\section{Genus: Torreya Arn.}

The genus Torreya includes six species which are distributed in the world as evergreen tree or shrubs (Farjon 2010). Out of these only three are reported from the study area vir: Torreya grandis, Torreya fargesii and Torreya jackii are reported from China. The wood of Torreya grandis and Torreya fargesii is used in construction of houses, furniture and bridges, for making utensils and for wood turning. Along with these uses Torreya grandis is also used as food and medicine to treat cough. Whereas in case of Torreyajackii no such uses are reported. This species is only used in making agricultural implements, utensils, handicrafts and as firewood.

\section{DISCUSSION AND CONCLUSION}

The overall study reflects the fact that the family is not considerably studied from ethnobotanical point of view. The Taxaceae got all its attention and which is also a cause of it's overharvesting only after 'Taxol' an anti-cancerous drug has been isolated from it in 1967 (Wani et al. 1971). 
Table 1. Distribution of Taxaceae in the study areas and their conservation status according IUCN Red List Categories [Abbreviations used, IUCN Categories: EN - Endangered; LC - Least Concern; NT - Near Threatened; VU - Vulnerable]

\begin{tabular}{|c|c|c|c|}
\hline Name of the Species & Common Name & Distribution & $\begin{array}{c}\text { IUCN Red } \\
\text { List Category }\end{array}$ \\
\hline Amentotaxus assamica D.K.Ferguson & Assam Catkin Yew & India $^{1,2,3} ;$ Myanmar $^{4}$ & $\mathrm{EN}$ \\
\hline Amentotaxus argotaenia (Hance) Pilg. & Catkin Yew & $\begin{array}{l}\text { China } 5,6,7,8 ; \operatorname{Laos}^{7,9,10,11,12,8} \\
\text { Vietnam } \\
9,7,8\end{array}$ & NT \\
\hline Amentotaxus formosana H.L.Li & Taiwan Catkin Yew & China $^{6,10,14}$ & $\mathrm{VU}$ \\
\hline $\begin{array}{l}\text { Amentotaxus poilanei (Ferré \& } \\
\text { Rouane) D.K.Ferguson }\end{array}$ & $\begin{array}{l}\text { Poilane's Catkin } \\
\text { Yew }\end{array}$ & Vietnam $^{6,7,33}$ & VU \\
\hline Amentotaxus yunnanensis H.L.Li & Yunnan Catkin Yew & $\begin{array}{l}\text { China }^{6,7,15} ; \text { Vietnam }^{7,15} ; \text { Laos } \\
2,11,12,15\end{array}$ & VU \\
\hline Cephalotaxus fortunei Hook. & Fortune's Yew Plum & China $^{19} ;$ Myanmar $^{19}$ & LC \\
\hline $\begin{array}{l}\text { Cephalotaxus harringtonii (Knight ex } \\
\text { J.Forbes) K.Koch }\end{array}$ & $\begin{array}{l}\text { Harrington's Plum } \\
\text { Yew }\end{array}$ & China $^{16}$ & LC \\
\hline Cephalotaxus hainanensis H.L.Li & Hainan Plum Yew & China $^{17}$ & EN \\
\hline Cephalotaxus lanceolata K.M.Feng & $\begin{array}{l}\text { Gongshan Plum } \\
\text { Yew }\end{array}$ & China $^{20}$ & $\mathrm{EN}$ \\
\hline $\begin{array}{l}\text { Cephalotaxus latifolia W.C.Cheng \& } \\
\text { L.K.Fu ex L.K.Fu \& R.R.Mill }\end{array}$ & $\begin{array}{l}\text { Broad-leaved Plum } \\
\text { Yew }\end{array}$ & China $^{9}$ & NT \\
\hline Cephalotaxus mannii Hook.f. & Mann's Yew Plum & $\begin{array}{l}\text { China }^{2,7,21} ; \text { India }^{7,21} ; \\
\text { Laos }^{2,7,11,12,21} ; \text { Myanmar } \\
\text { Thailand } \\
\text { Th, }\end{array}$ & VU \\
\hline Cephalotaxus oliveri Mast. & Oliver's Plum Yew & China $^{22}$ & VU \\
\hline $\begin{array}{l}\text { Cephalotaxus sinensis (Rehd. \& } \\
\text { E.H.Wilson) H.L.Li }\end{array}$ & Chinese Plum Yew & China $^{18}$ & LC \\
\hline $\begin{array}{l}\text { Pseudotaxus chienii (W.C Cheng) } \\
\text { W.C.Cheng }\end{array}$ & White-berry Yew & China $^{29}$ & VU \\
\hline Taxus chinensis (Pilg.) Rehd. & Chinese Yew & China $^{7,27}$; Vietnam ${ }^{7,27}$ & $\mathrm{EN}$ \\
\hline Taxus contorta Griff. & $\begin{array}{l}\text { West Himalayan } \\
\text { Yew }\end{array}$ & $\begin{array}{l}\text { China }^{38} ; \text { India }^{38} ; \\
\text { Nepal }^{23,24,26,38}\end{array}$ & $\mathrm{EN}$ \\
\hline Taxus cuspidata Siebold \& Zucc. & Japanese Yew & China $^{28}$ & LC \\
\hline $\begin{array}{l}\text { Taxus mairei (Lemée \& Lévl.) } \\
\text { S.Y.Hu ex Liu }\end{array}$ & Maire's Yew & $\begin{array}{l}\text { China }^{23,34} ; \text { Nepal }^{23,24}, \\
\text { Bhutan }^{23}, \text { Vietnam } \\
\end{array}$ & $\overline{\mathrm{VU}}$ \\
\hline Taxus wallichiana Zucc. & $\begin{array}{l}\text { East Himalayan } \\
\text { Yew }\end{array}$ & 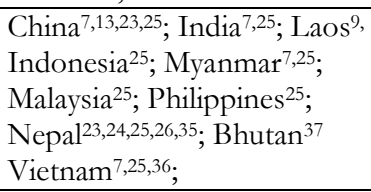 & EN \\
\hline Torreya fargesii Franch. & Farges Nutmeg Tree & China $^{30}$ & VU \\
\hline Torreya grandis Fortune ex Lindl. & $\begin{array}{l}\text { Chinese Nutmeg } \\
\text { Tree }\end{array}$ & China $^{31}$ & LC \\
\hline Torreya jackii Chun & Jack's Nutmeg Tree & China $^{32}$ & $\mathrm{EN}$ \\
\hline
\end{tabular}

[REFERENCES: 1-Thomas et al. 2013a; 2- Gajurel et al. 2006; 3- Ferguson 1985; 4- Ding et al. 2019; 5Hilton-Taylor et al. 2013b; 6- Ho et al. 2012; 7- Loc et al. 2017; 8- Gao et al. 2019a; 9- Farjon 2013; 10- Fu et al. 1999b; 11- Thomas et al. 2007; 12- Averyanov et al. 2014; 13- Gao et al. 2019b; 14- Thomas 2013; 15Thomas et al. 2017; 16- Yang et al. 2013b; 17- Yang \& Liao 2013a; 18- Farjon et al. 2013; 19- Hilton-Taylor et al. 2013a; 20- Yang \& Liao 2013b; 21- Liao \& Yang 2013a; 22- Liao \& Yang 2013b; 23- Poudel et al. 2012; 24Poudel et al. 2013; 25- Thomas \& Farjon 2011; 26- Gajurel \& Gautam 2016; 27- Thomas et al. 2013b; 28Katsuki \& Luscombe 2013; 29- Thomas \& Yang 2013; 30- Yang \& Luscombe 2013a; 31- Yang \& Luscombe 2013b; 32- Yang \& Luscombe 2013c; 33- Nguyen et al. 2013; 34- Yang et al. 2013a; 35- Thapa 2012; 36- Gao et al. 2007; 37- Wangyal 2012; 38- Thomas 2011] 
Table 2. Ethnobotanical uses of Taxaceae

\begin{tabular}{|c|c|c|}
\hline Name of the Species & Vernacular Name & Ethnobotanical Uses \\
\hline Amentotaxus assamica & India- Sanglee ${ }^{1,2}$ & India- House construction $^{1,2}$, fuelwood ${ }^{1}$ \\
\hline Amentotaxus argotaenia & $\begin{array}{l}\text { China- Sui Hua Shan } 3,4,5 \\
\text { Vietnam- Dẻ tùng sọc trắng hẹp }{ }^{4} \text {, } \\
\text { Sam bông sọc trắng hẹp }{ }^{4} \text {, Sam hoa } \\
\text { bông sọc hẹp }\end{array}$ & $\begin{array}{l}\text { Vietnam- Tool making }{ }^{3,4}, \text { furniture }^{3,4,6} \text {, } \\
\text { wood turning } 3,4,6, \text { local construction }^{6} \text {, } \\
\text { medicine }^{7} \\
\text { Laos- Medicine }^{7}\end{array}$ \\
\hline Amentotaxus formosana & China- Tai Wan Sui Hua Shan $5,8,9$ & $\begin{array}{l}\text { China- Furniture }{ }^{5,8,9}, \text { farm implements }{ }^{5,8,9} \text {, } \\
\text { utensils } s^{5,8,9} \text {, handicrafts }{ }^{9} \text {, wood turning } \\
\text { (souvenirs) }{ }^{5,8}\end{array}$ \\
\hline Amentotaxus poilanei & $\begin{array}{l}\text { Vietnam- De Tung Poa } \operatorname{Ian}^{12}, \text { Dẻ } \\
\text { tùng Nam }{ }^{4,5,12} \text {, Sam bông Nam }{ }^{4,5,12} \text {, } \\
\text { Sam hoa bông ngọc pan }\end{array}$ & Vietnam- Medicine ${ }^{7}$ \\
\hline Amentotaxus yunnanensis & $\begin{array}{l}\text { China-Yunnan Sui Hua Shan } \text { Sh, }^{4,5,10} \\
\text { Vietnam- Dè tùng Vân Nam }{ }^{4,5,10}, \\
\text { Thông tre Vân Nam }{ }^{4} \text {, Sam bông sọc } \\
\text { trắng rộng }{ }^{4}, \text { Sam hoa bông sọc rộng }\end{array}$ & 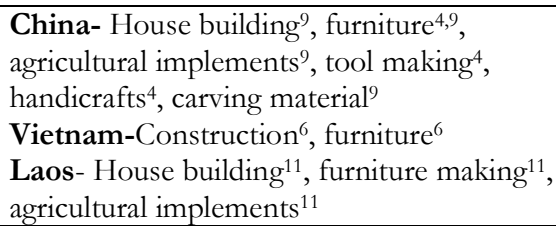 \\
\hline Cephalotaxus fortunei & $\begin{array}{l}\text { China- San jian shan }{ }^{5,14,22} \text {, Yuan bian } \\
\text { zhong }^{5,22}\end{array}$ & $\begin{array}{l}\text { China- Lamp oil }{ }^{22}, \text { decoration }^{5} \\
\text { horticulture }^{5}\end{array}$ \\
\hline Cephalotaxus hainanensis & China- Hai nan $\mathrm{cu} \mathrm{fei}^{5,16}$ & Medicine (leukemia) ${ }^{17,18,19}$ \\
\hline Cephalotaxus harringtonii & China- No Record & Medicine (anthelminthic) ${ }^{15}$ \\
\hline Cephalotaxus lanceolata & China- Gong Shan San Jian Shan $5,14,23$ & China- Firewood ${ }^{23}$, construction ${ }^{23}$ \\
\hline Cephalotaxus latifolia & China- Kuan ye cu fei ${ }^{5,13,14}$ & No record 5,13 \\
\hline Cephalotaxus mannii & $\begin{array}{l}\text { China- Hai nan cu fei }{ }^{4,5,24} \\
\text { India- Tufar }{ }^{25}, \text { Kelingsang }^{26} \\
\text { Vietnam -Dinh tung } \\
\text { mui } 5,5,5,5,24 \\
\text { Thailand-Ma Kham pom dong }{ }^{27}\end{array}$ & 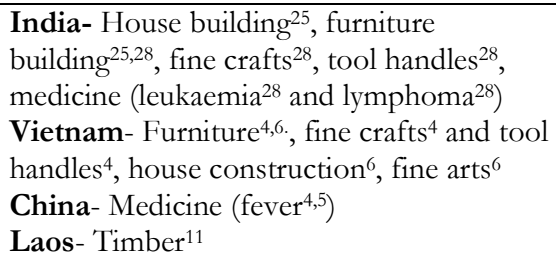 \\
\hline Cephalotaxus sinensis & China- Cu fei ${ }^{5,14,20}$ & 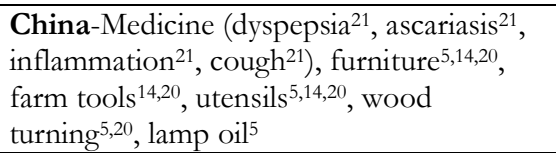 \\
\hline Cephalotaxus oliveri & China- Bi zi san jian shan $5,14,29$ & Not Found \\
\hline Pseudotaxus chienii & China- Bai dou shan ${ }^{5,9,70}$ & China- Carving material ${ }^{5,9,70}$, utensils ${ }^{5,9,70}$ \\
\hline Taxus chinensis & $\begin{array}{l}\text { China- Hongdoushan } 5,4,66,67,68 \\
\text { Vietnam- Thong do Bacc,5,67, Thông } \\
\text { đỏ đá vôi (Thông đỏ bắc) }{ }^{6}\end{array}$ & 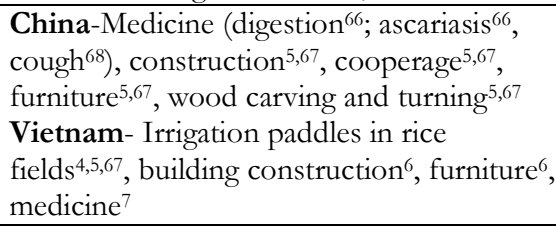 \\
\hline Taxus contorta & 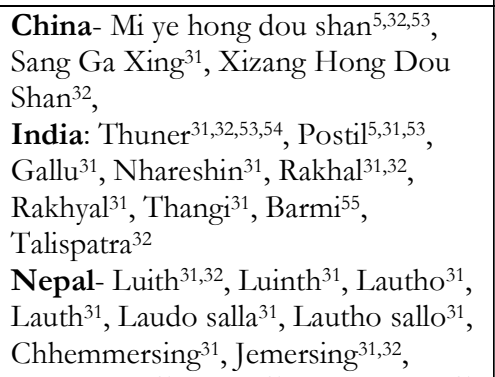 & 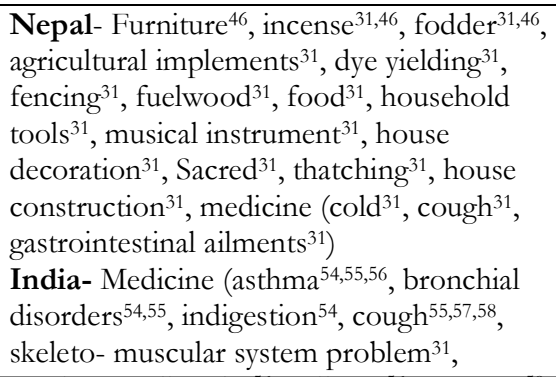 \\
\hline
\end{tabular}




\begin{tabular}{|c|c|c|}
\hline Name of the Species & Vernacular Name & Ethnobotanical Uses \\
\hline $\begin{array}{l}\text { Taxus contorta } \\
\text { [contd.] }\end{array}$ & $\begin{array}{l}\text { Chyangsing }{ }^{31}, \text { Silingi }^{31}, \text { Jhamarshing }^{31} \text {, } \\
\text { Sanga Sing } \\
\text { Dhengre }^{32} \text {, Tongsa Sing }\end{array}$ & 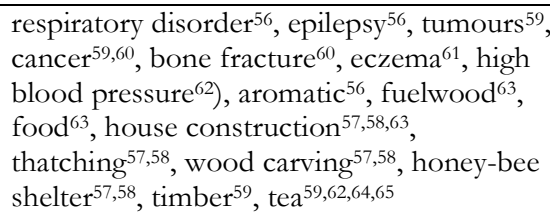 \\
\hline Taxus cuspidate & China- Dong bei hong dou shan ${ }^{9}$ & $\begin{array}{l}\text { China- Building construction }{ }^{5,9,69} \text {, wood } \\
\text { turning }{ }^{5,69} \text {, furniture }{ }^{5,9,69} \text {, carving } \\
\text { material }{ }^{5,9,69} \text {, cooperage }{ }^{5,69}, \text { medicine } \\
\left(\text { diabetes }^{5,9}\right) \text {. }\end{array}$ \\
\hline Taxus mairei & $\begin{array}{l}\text { China- Nan fang hong dou shan }{ }^{5,9,30,31} \\
\text { Nepal- Dhengre }^{32} \text {, Lauth Salla }{ }^{31,32}, \\
\text { Barme Salla } \\
\text { Talispatra }^{32}, \text { Sallo } \\
\text { Bhutan- Dhengrey Salla } \\
\text { Vietnam- Thong Do Lam Dong }{ }^{32,33}, \\
\text { Thong Do La Dai }{ }^{32,33} \text {, Thong Do } \\
\text { Nam }^{32,33}\end{array}$ & $\begin{array}{l}\text { China-Wine and tea making }{ }^{30} \text {, agricultural } \\
\text { tools }^{5,30} \text {, building material }{ }^{5,30} \text {, furniture } \\
\text { household tools }^{51} \text {, stationery } \\
\text { Nepal- Agricultural implements } \\
\text { bedding }^{31} \text {, animal } \\
\text { sood }^{31} \text {, house decoration } \\
\text { sacred }^{31} \text {, house construction } \\
\text { (gastrointestinal ailments }^{31}, \text { stimulant }^{31} \text {, } \\
\text { fever }^{31}, \text { cancer }^{31} \text { ) }\end{array}$ \\
\hline Taxus wallichiana & 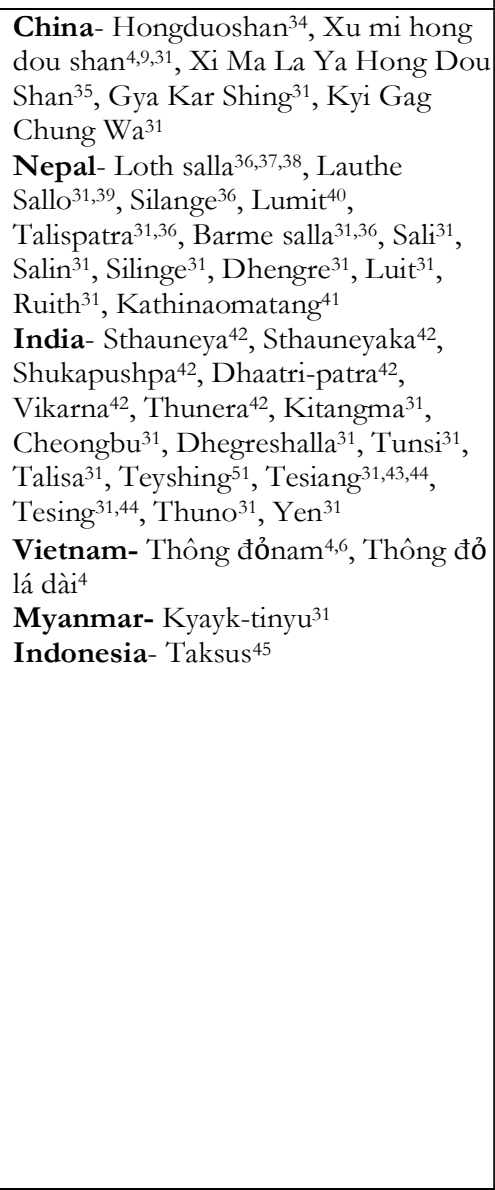 & 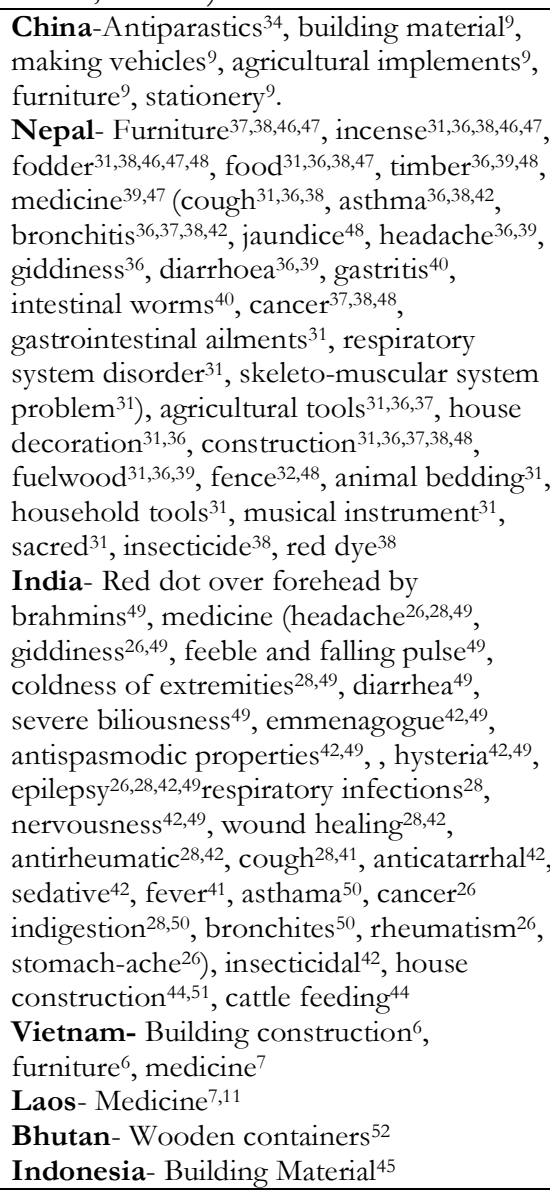 \\
\hline Torreya fargesii & China- Ba Shan Fei Shu $5,9,72$ & $\begin{array}{l}\text { China- Building houses } 5,9,72 \text {, bridges } 5,9,72 \\
\text { furniture }^{5,9,72} \text {, utensils } \\
5,9,72 \text {, wood turning } 5,72\end{array}$ \\
\hline Torreya grandis & $\begin{array}{l}\text { China- Fei Shu }{ }^{5,9,71} \text {, Yuan Bian } \\
\text { Zhong, }\end{array}$ & 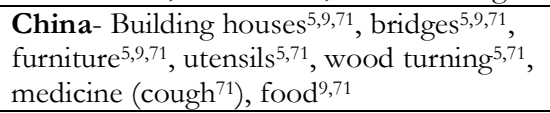 \\
\hline Torreya jackii & China- Chang Ye Fei Shu ${ }^{5,9,73}$ & $\begin{array}{l}\text { China- Agricultural implements } 5,9,73 \\
\text { utensils }^{5,9,73} \text {, handicrafts } \\
5,9,73 \text {, firewood }\end{array}$ \\
\hline
\end{tabular}


Though locally their twigs, bark and leaves were and still are used by local inhabitants in various forms in their day to day life in India, China and other parts of SE Asia. The species are mentioned to be used in many traditional documents such as in Unani system of medicine (Datta \& Jha 2001; Khare 2008) and Traditional Chinese Medicine (Siow et al. 2005; Efferth et al. 2007).

From the study it is found that out of the five genera documented Amentotaxus, Cephalotaxus and Torreya need further detailed studies regarding traditional uses of species as there is insufficient recorded information. Currently, when the traditional knowledge of plants is rapidly declining due to modernisation of villages, availability of modern quick fix medicines, transformation of forested land with more cash yielding species, disinterested younger generation to hold on to the their traditional knowledge systems and more over their migration to greener revenue pastures; a collaborative indigenous-academia community based measure is the only solution to save and retrieve the age old traditional uses of biological systems. These will help in the prevention of exploitation of the natural habitats of the species and lead them to save at least some of the intact populations once they accept the ownership for their conservation.

The species are under threat due to various anthropogenic factors like deforestation, logging of trees for timber, forest fragmentation, land transformation, shifting cultivation and climate change (Sodhi et al. 2004; Xu et al. 2009; Uprety et al. 2011; Averyanov et al. 2014; Ding et al. 2019). The existence and survival of these species somewhat depends up on the knowledge and support of local inhabitants. One such example is the degrading population of Taxus contorta in Shimla district of Himachal Pradesh and Almora district of Uttarakhand due to scarcity of knowledge among some local people. Connecting religious beliefs and rituals to the plants by local communities not only help in protection but also help in conservation of these species. In India and Nepal, the species are linked to religious beliefs which help in their conservation. In Nepal Taxus mairei and Taxus wallichiana are considered as sacred, whereas in India Brahmins apply a red dot over the forehead made form Taxus wallichiana (Datta \& Jha 2001). Another instance of involvement of local communities in conservation of species was noted during field survey in Northeast India. Many mature trees of Taxus wallichiana which are growing inside Mawphlang Sacred groove and in Mukhla village are protected by local communities of Khasi and Jaintia Hills and are considered sacred. Therefore, conservation initiatives must include the collaboration among countries and with local communities in tracking the illegal trade of these species and other anthropogenic activities resulting in decline of species from their habitats. During the field exploration for taxads in Northeast states of India, we

[REFERENCS (Table - 2): 1- Gajurel et al. 2006; 2- Thomas et al. 2013a; 3- Hilton-Taylor et al. 2013b; 4Nguyen et al. 2004; 5- Farjon 2010; 6- Loc et al. 2017; 7- Hiep et al. 2015; 8- Thomas 2013; 9- Fu et al. 1999b; 10- Thomas et al.2017; 11- Averyanov et al.2014; 12- Nguyen et al. 2013; 13- Farjon 2013; 14- Fu et al. 1999a; 15- Efferth et al. 2007; 16- Yang \& Liao 2013a; 17-Tanvir et al. 2017; 18- Yang et al. 2015; 19-Huang et al. 2016; 20- Farjon et al. 2013; 21-Saeed et al. 2008; 22- Hilton-Taylor et al. 2013a; 23- Yang \& Liao 2013b; 24- Liao \& Yang 2013a; 25- Bhardwaj \& Gakhar 2008; 26- Zhasa et al. 2015; 27- Phengklai 1973; 28- Balkrishna et al. 2018; 29- Liao \& Yang 2013b; 30- Yang et al. 2013a; 31- Poudel et al. 2013; 32- Poudel et al. 2012; 33- Le et al. 2003; 34- Gao et al. 2019b; 35- Eckenwalder 2009; 36- Joshi 2009; 37- Kunwar \& Duwadee 2003; 38-Malla 2015; 39- Sigdel et al. 2013; 40- Thapa 2012; 41- Salam et al. 2016; 42- Khare 2008; 43- Nimasow et al. 2016; 44- Nimachow et al. 2010; 45- Sunandar et al. 2019; 46- Gajurel \& Gautam 2016; 47- Gajurel et al. 2014b; 48Gajurel et al. 2014a; 49- Datta \& Jha 2001; 50- Tiwari \& Chauhan 2006; 51- Kalita \& Khan 2013; 52- Wangyal 2012; 53- Thomas 2011; 54- Singh et al. 1990; 55- Rao et al. 2015; 56- Kala 2015; 57- Maikhuri et al. 1998; 58Nimasow et al. 2015; 59- Kala 2007; 60- Negi et al. 2018; 61- Agarwal 2019; 62- Singh et al. 2019; 63- Pant \& Pant 2011; 64- Mukherjee et al. 2018; 65- Rana et al. 2019; 66- Hong et al. 2015; 67- Thomas et al. 2013b; 68Siow et al. 2005; 69- Katsuki \& Luscombe 2013; 70- Thomas \& Yang 2013; 71- Yang \& Luscombe 2013b; 72- Yang \& Luscombe 2013a; 73- Yang \& Luscombe 2013c] 
could not locate any wild locality of Cephalotaxus thus, it seems even local indigenous communities have lost all the ethnic knowledge and information related to at least Cephalotaxus mannii.

The conclusion drawn from the study is that Taxaceae being one of the important gymnospermic family needs much more attention from conservation point of view. Priority should be given to involvement of tribal or indigenous communities in conservation strategies and documentation of the ethnobotanical knowledge. The tribal or local communities are the store houses of vast ethnobotanical knowledge but this knowledge is slowly getting degraded due to lack of transmission to the next generation and migration of younger generation to urban areas. Scientific investigations on these plants are attracting various industries and pharmaceutical companies is creating threat and overexploitation of these species as they lure indigenous people with quick money. So, it is important to framing strategies for conservation, developing techniques of mass-propagation using local and scientific knowledge to use them sustainably over a longer period of time and revenue generation should be an important angle to this strategy.

\section{Acknowledgements}

Authors are thankful to Guru Gobind Singh Indraprastha University, Delhi for providing financial assistance (Short Term Research Fellowship and Faculty Research Grant Scheme 2019 - 2020) and all facilities during the research work.

\section{LITERATURE CITED}

Agarwal, R. 2019. Ethnobotanical studies of medicinal plants in Chopta-Mandal forest of Garhwal Himalayas in Uttarakhand. J Pharmacogn Phytochem. 8(2): 774 - 776.

Averyanov, L.V.; Nguyen, T.H.; Sinh, K.N.; Pham, T.V.; Lamxay, V.; Bounphanmy, S.; Lorphengsy, S.; Phan, L.K.; Lanorsavanh, S. \& Chantthavongsa, K. 2014. Gymnosperms of Laos. Nordic J. Bot. 32(6): $765-805$.

Azaizeh, H.; Fulder, S.; Khalil, K. \& Said, O. 2003. Ethnomedicinal knowledge of local Arab practitioners in the Middle East Region. Fitoterapia 74(1-2): 98 -108.

Badola, H.K. 2017. Biocultural knowledge for biodiversity conservation: some Himalayan endorsements. Biodiversity 18(4): $212-218$.

Balkrishna, A.; Prajapati, U.B.; Srivastava, A. \& Mishra, R. 2018. Phytoetymology and ethnobotany of indigenous or introduced gymnosperms in India. Int. J. Unani. Integ. Med. 2(4): $44-51$.

Bhardwaj, S. \& Gakhar, S.K. 2008. Ethnobotanicals used by tribals of Mizoram for furniture and household equipments. Indian J. Trad. Knowl. 7(1): $134-137$.

Calixto, J.B. 2005. Twenty-five years of research on medicinal plants in Latin America. a personal view. J Ethnopharmacol. 100: 131 - 134.

Cheng, Y.; Nicolson, R.G.; Tripp, K. \& Chaw, S-M. 2000. Phylogeny of Taxaceae and Cephalotaxaceae Genera Inferred from Chloroplast matK Gene and Nuclear rDNA ITS Region. Mol. Phylogenet. Evol. 14: 353 - 365.

Convention on Biological Diversity. 2012. Global Strategy for Plant Conservation: 2011-2020. Botanic Gardens Conservation International, Richmond, UK.

Cook, G. \& Offit, T. 2008. Pluralism and transculturation in indigenous maya religion. Ethnology 47: $45-59$.

Dalle, S.P. \& Potvin, C. 2004. Conservation of useful plants: an evaluation of local priorities from two indigenous communities in eastern Panama. Econ Bot. 58(1): 38 - 57. 
Datta, M.M. \& Jha, S. 2001. Some observations on the Himalayan Yew: Taxus wallichiana. J. Trop. Med. Plants. 2(2): $245-251$.

Ding, H-B.; Yang, B.; Zhou, S-S.; Maw, M.B.; Maung, K.W. \& Tan, Y-H. 2019. New contributions to the flora of Myanmar I. Plant Divers. 41: 135 - 152.

Eckenwalder, J.E. 2009. Conifers of the World: The complete Reference. Timber Press, Inc.

Efferth, T.; Li, P.C.; Konkimalla, V.S.B. \& Kaina, B. 2007. From traditional Chinese medicine to rational cancer therapy. Trends Mol. Med. 13(8): 353 - 361.

Farjon, A. 2010. A Handbook of the World's Conifers. Koninklijke Brill, Leiden.

Farjon, A. 2013. Cephalotaxus latifolia. The IUCN Red List of Threatened Species 2013: e.T42199A2960388.http:/ / dx.doi.org/10.2305/IUCN.UK.20131.RLTS.T42199A2960388.en

Farjon, A.; Rushforth, K. \& Christian, T. 2013. Cephalotaxus sinensis. The IUCN Red List of Threatened Species 2013: e.T42200A2960468. http://dx.doi.org/10.2305/ IUCN.UK.2013-1.RLTS.T42200A2960468.en

Ferguson, D.K. 1985. A New Species of Amentotaxus (Taxaceae) from Northeastern India. Kew Bulletin 40(1): 115 - 119.

Fu, L-G.; Li, N. \& Mill, R.R. 1999a. Cephalotaxus Sieb. et Zucc. In: Wu, Z.Y. \& Raven, P.H. (eds.), Flora of China 4. Beijing, China: Science Press and St. Louis, MO, USA: Missouri Botanical Garden Press. Pp. $85-88$.

Fu, L-G.; Li, N. \& Mill, R.R. 1999b. Taxaceae. In: Wu, Z.Y. \& Raven, P.H. (eds.), Flora of China 4. Beijing, China: Science Press and St. Louis, MO, USA: Missouri Botanical Garden Press. Pp. $89-96$.

Gajurel, J.P.; Shrestha, K.K.; Werth, S. \& Scheidegger, C. 2014a. Taxus wallichiana (Himalayan Yew) for the livelihood of local people in some protected areas of Nepal. J. Nat. Hist. Mus. 28: $1-8$.

Gajurel, J.P.; Werth, S.; Shrestha, K.K. \& Scheidegger, C. 2014b. Species distribution modelling of Taxus wallichiana (Himalayan Yew) in Nepal Himalaya. Asian J. Conserv. Biol. 3(2): 127 - 134.

Gajurel, J.P. \& Gautam, M. 2016. Notes on anatomy and morphology of Taxus mairei (cultivated yew) from Nepal. Golden Gate Journal of Science \& Technology 2: 67 - 70.

Gajurel, P.R.; Bora, P.J.; Muthu, J. \& Sarmah, A. 2006. Status and conservation aspects of Amentotaxus assamica- A critically endangered Gymnosperm in Arunachal Pradesh, Eastern Himalaya. Phytotaxonomy 6: $39-44$.

Gao, L-M.; Möller, M.; Zhang, X M.; Hollingsworth, M.L.; Liu, J.; Mill, R.R.; Gibby, M. \& Li, D Z. 2007. High variation and strong phylogeographic pattern among cpDNA haplotypes in Taxus wallichiana (Taxaceae) in China and North Vietnam. Mol. Ecol. 16(22): 4684 - 4698.

Gao, L-M.; Tan, S-L.; Zhang, G-L. \& Thomas, P. 2019a. A new species of Amentotaxus (Taxaceae) from China, Vietnam, and Laos. PhytoKeys 130: 25 - 32.

Gao, L.; Wei, N.; Yang, G.; Zhang, Z.; Liu, G. \& Cai, C. 2019b. Ethnomedicine study on traditional medicinal plants in the Wuliang Mountains of Jingdong, Yunnan, China. J. Ethnobiology Ethnomedicine 15: 41.

Ghimire, B. \& Heo, K. 2014. Cladistic analysis of Taxaceae s.l. Plant Syst. Evol. 300: 217 - 223.

Gonçalves, P.H.S.; Albuquerque, U.P. \& Medeiros, P.M.D. 2016. The most commonly available woody plant species are the most useful for human populations: a meta-analysis. Ecol. Appl. 26(7): 2238 - 2253. 
Hao, D.C.; Xiao, P.G.; Huang, B.L.; Ge, G.B. \& Yang, L. 2008. Interspecific relationships and origins of Taxaceae and Cephalotaxaceae revealed by partitioned Bayesian analyses of chloroplast and nuclear DNA sequences. Plant Syst. Evol. 276: 89 - 104.

Hiep, N.T.; Khang, N.S. \& Loc, P.K. 2015. Gymnosperms of Indochina. Age 1: 134

Hilton-Taylor, C.; Liao, W. \& Yang, Y. 2013a. Cephalotaxus fortunei. The IUCN Red List of Threatened Species 2013: e.T42198A2960338. http://dx.doi.org/10.2305/ IUCN.UK.2013-1.RLTS.T42198A2960338.en

Hilton-Taylor, C.; Yang, Y.; Rushforth, K. \& Liao, W. 2013b. Amentotaxus argotaenia. The IUCN Red List of Threatened Species 2013: e.T42545A2986540. http://dx.doi.org/10.2305/ IUCN.UK.2013-1.RLTS.T42545A2986540.en.

Ho, C.S.; Chen, C.T.; Ko, Y.Z.; Ge, X.J.; Hung, K.H.; Hsu, T.W. \& Chiang, Y.C. 2012. Isolation and characterization of 15 microsatellite loci in four endangered Amentotaxus species (Taxaceae). Am J. Bot. 99(4): e157 - e159.

Hong, L.; Zhuo, J.; Lei, Q.; Zhou, J.; Ahmed, S.; Wang, C.; Long, Y.; Li, F. \& Long, C. 2015. Ethnobotany of wild plants used for starting fermented beverages in Shui communities of southwest China. J. Ethnobiology Ethnomedicine 11(1): 42.

Huang, W.; Li, P.; Liu, Y.; Huang, W.; Ju, Y.; Wang, J.; Ntumwel, C.B. \& Long, C. 2016. Ethnobotanical study on medicinal plants used by Li people in Ledong, Hainan Island, China. Acta Soc Bot Pol. 85(1): 3485.

Joshi, K. 2009. Taxus wallichiana (Himalayan Yew; Loth salla) in Nepal: Indigenous Uses, Conservation and Agenda for Sustainable Management. Ethnobotl Leaflets 13: 1504 - 1508.

Kahlon, L.K. \& Singh, R. 2018. Current status of biocultural knowledge of Paudi Bhuyan, a particularly vulnerable tribal group (PVTG) in Northern Odisha, India. Intn. J. Res. Anal. Rev. 5(3): 217a-223a.

Kala, C.P. 2007. Local preferences of ethnobotanical species in the Indian Himalaya: Implications for environmental conservation. Curr. Sci. 93(12): 1828 - 1834.

Kala, C.P. 2015. Medicinal and Aromatic Plants of Tons Watershed in Uttarakhand Himalaya. Appl. Ecol. Env. Res. 3(1): 16 - 21.

Kalita, J. \& Khan, M.L. 2013. Medicinal plants from the high altitudes of the western part of Arunachal Pradesh, India and their trade. Intn. J. Conserv. Sci. 4(3): 337 - 346.

Katsuki, T. \& Luscombe, D. 2013. Taxus cuspidata. The IUCN Red List of Threatened Species 2013: e.T42549A2987373. http://dx.doi.org/10.2305/IUCN.UK.20131.RLTS.T42549A2987373.en .

Khare, C.P. 2008. Indian medicinal plants: an illustrated dictionary. Springer Science \& Business Media.

Koyama, J.; Morita, I.; Kobayashi, N.; Hirai, K.; Simamura, E.; Nobukawa, T. \& Kadota, S. 2006. Antiallergic activity of aqueous extracts and constituents of Taxus yunnanensis. Biol Pharm. Bull. 29: 2310 - 2312.

Kunwar, R.M. \& Duwadee, N.P.S. 2003. Ethnobotanical notes on flora of Khaptad National Park (KNP), far-western Nepal. Himalayan J. Sci. 1(1): 25 - 30.

Le, D.K.; Nguyen, X.L.; Nguyen, H.N.; Ha, H.T.; Hoang, S.D.; Nguyen, H.Q. \& Vu, V.M. 2003. Forest tree species selection for planting programmes in Vietnam. Ministry of Agriculture and rural development forest sector support programmes and partners, Hanoi.

Liao, W. \& Yang, Y. 2013a. Cephalotaxus mannii. The IUCN Red List of Threatened Species 2013: e.T18625568A2804770. http://dx.doi.org/10.2305/IUCN.UK.20131.RLTS.T18625568A2804770.en 
Liao, W. \& Yang, Y. 2013b. Cephalotaxus oliveri. The IUCN Red List of Threatened Species 2013: e.T32331A2815247. http://dx.doi.org/10.2305/IUCN.UK.20131.RLTS.T32331A2815247.en

Loc, P.K.; The, P.V.; Long, P.K.; Regalado, J.; Averyanov, L. \& Maslin, B. 2017. Native conifers of Vietnam- A review. Pakistan J. Bot. 49(5): 2037 - 2068.

Maikhuri, R.K.; Nautiyal, S. \& Rao, K.S. 1998. Role of medicinal plants in traditional health care system: A case study from Nanda Devi Biosphere Reserve. Curr. Sci. 75: 152 - 157.

Malla, B. 2015. Ethnobotanical study on medicinal plants in Parbat district of western Nepal. Ph.D. Thesis, Kathmandu University, Dhulikhel, Nepal.

Mao, A.A.; Hynniewta, T.M. \& Sanjappa, M. 2009. Plant wealth of northeast India with reference to Ethnobotany. Ind. J. Trad. Knowl. 8(1): $96-103$.

Mukherjee, A.; Joshi, K.; Pal, R.S.; Ga, A.; Roy, M.L. \& Chandra, N. 2018. Scientific health benefits of Namakeen Chai/Jya (Salted Tea): A traditional tea beverage of Bhotiya tribal community in higher altitudes of Uttarakhand. Ind. J. Trad. Knowl. 17(2): 365 - 369.

Negi, V.S.; Maikhuri, R.K.; Maletha, A. \& Phondani, P.C. 2018. Ethnobotanical Knowledge and Population Density of Threatened Medicinal Plants of Nanda Devi Biosphere Reserve, Western Himalaya, India. Iran. J. Sci. Technol. Trans. A Sci. 43(1): 63 - 73.

Nguyen, T.H.; Phan, K.L.; Nguyen, N.D.T.L.; Thomas, P.I.; Farjon, A.; Averyanov, L. \& Regalado, J. 2004. Vietnam Conifers: Conservation Status Review. Hanoi: Fauna and Flora International, Vietnam Program. Pp.102-109.

Nguyen, T.H.; Phan, K.L.; Nguyen, Q.H. \& Thomas, P. 2013. Amentotaxus poilanei. The IUCN Red List of Threatened Species 2013: e.T34416A2852278. http://dx.doi.org/10.2305/ IUCN.UK.2013-1.RLTS.T34416A2852278.en

Nimasow, G.; Nimasow, O.D.; Rawat, J.S.; Tsering, G. and Litin, T. 2016. Remote sensing and GIS-based suitability modeling of medicinal plant (Taxus baccata Linn.) in Tawang district, Arunachal Pradesh, India. Curr. Sci. 110(2): 219 - 227.

Nimasow, G.; Nimasow, O.D. \& Tsering, G. 2015. Vanishing Taxus baccata L. due to Unsustainable Exploitation and Climate Change in West Kameng and Tawang Districts of Arunachal Pradesh. Earth Sciences 4(3-1): 11 - 18.

Nimachow, G.; Rawat, J.S. \& Dai, O. 2010. Status of Himalayan yews in West Kameng district of Arunachal Pradesh. Curr. Sci. 98(11): $1434-1437$.

Nisar, M.; Khan, I.; Simjee, S.U.; Gilani, A-H. \& Obaidullah, P.H. 2008. Anticonvulsant, analgesic and antipyretic activities of Taxus wallichiana Zucc. J. Ethnopharmacol. 116: 490 - 494.

Pant, S. \& Pant, V.S. 2011. Status and Conservation Management Strategies for Threatened Plants of Jammu and Kashmir. J. Phytol. 3(7): 50 - 56.

Pei, S.; Zhang, G. \& Huai, H. 2009. Application of traditional knowledge in forest management: Ethnobotanical indicators of sustainable forest use. For. Ecol. Manag. 257(10): 2017 - 2021.

Phengklai, C. 1973. Studies in Flora of Thailand: Cephalotaxaceae. Thai Forest Bulletin (Botany) 7: $7-8$.

Phumthum, M.; Srithi, K.; Inta, A.; Junsongduang, A.; Tangjitman, K.; Pongamornkul, W.; Trisonthi, C. \& Balslev, H. 2018. Ethnomedicinal plant diversity in Thailand. J Ethnopharmacol. 214: 90 - 98.

Pieroni, A., Sõukand, R., Quave, C.L., Hajdari, A., Mustafa, B. 2017. Traditional food uses of wild plants among the Gorani of South Kosovo. Appetite 108: 83 - 92. 
14 Ethnobotanical notes on Taxaceae

Poudel, R.C.; Gao, L.M.; Möller, M.; Baral, S.R.; Uprety, Y.; Liu, J. \& Li, D-Z. 2013. Yews (Taxus) along the Hindu Kush-Himalayan region: exploring the ethnopharmacological relevance among communities of Mongol and Caucasian origins. J. Ethnopharmacol147(1): $190-203$.

Poudel, R.C.; Möller, M.; Gao, L-M.; Ahrends, A.; Baral, S.R.; Liu, J.; Thomas, P. \& Li, D-Z. 2012. Using Morphological, Molecular and Climatic Data to Delimitate Yews along the Hindu Kush-Himalaya and Adjacent Regions. PLoS ONE 7(10): e46873.

Price, R.A. 1990. The Genera of Taxaceae in the Southern United States. J. Arnold Arb. 71: 69 - 91.

Rai, P.K. \& Lalramnghinglova, H. 2010. Lesser known ethnomedicinal plants of Mizoram, North East India: an Indo-Burma hotspot region. J. Med. Pl. Res. 4(13): 1301 - 1307.

Rana, D.; Bhatt, A. \& Lal, B. 2019. Ethnobotanical knowledge among the semi-pastoral Gujjar tribe in the high altitude (Adhwari's) of Churah subdivision, district Chamba, Western Himalaya. J. Ethnobiology Ethnomedicine 15(1): 10.

Rao, P.K.; Hasan, S.S.; Bhellum, B.L. \& Manhas, R.K. 2015. Ethnomedicinal plants of Kathua district, J \& K, India. J. Ethnopharmacol 171: 12 - 27.

Saeed, M.K.; Deng, Y. \& Dai, R. 2008. Attenuation of biochemical parameters in streptozotocininduced diabetic rats by oral administration of extracts and fractions of Cephalotaxus sinensis. J. Clin. Biochem. Nutr. 42(1): $21-28$.

Saeed, M.K.; Deng, Y.; Dai, R.; Li, W.; Yu, Y. \& Iqbal, Z. 2010. Appraisal of antinociceptive and anti-inflammatory potential of extract and fractions from the leaves of Torreya grandis Fort ex. Lindl. J. Ethnopharmacol. 127(2): 414 - 418.

Salam, S.; Jamir, N.S. \& Roma, M. 2016. Ethnobotanical remedies to cough and cold as practiced by the Tangkhul tribe in the Ukhrul District of Manipur, India. Pleione 10(1): 66 - 70.

Sigdel, S.R.; Rokaya, M.B. \& Timsina, B. 2013. Plant inventory and ethnobotanical study of Khimti hydropower project, central Nepal. Sci. World 11: $105-112$.

Simpson, M.G. 2010. Plant Systematics. Second Edition, Elsevier Inc.

Singh, A.; Hart, R.; Chandra, S.; Nautiyal, M.C. \& Sayok, A.K. 2019. Traditional Herbal Knowledge among the Inhabitants: A Case Study in Urgam Valley of Chamoli Garhwal, Uttarakhand, India. Evid. Based. Complement. Alternat. Med. eCAM 2019: 5656925.

Singh, H.; Saklani, A. \& Lal, B. 1990. Ethnobotanical observations on some gymnosperms of Garhwal Himalaya, Uttar Pradesh, India. Econ Bot. 44(3): 349 - 354.

Singh, R.; Biswas, J. \& Bisht, S. 2018. Gymnosperm diversity of the Himalayan Biodiversity Hotspot. In: Das, A.P. \& Bera, S. (eds.), Plant Diversity in the Himalaya Hotspot Region. Vol I, Bishen Singh Mahendra Pal Singh, New Connaught Place, Dehra Dun.

Siow, Y.L.; Gong, Y.; Au-Yeung, K.K.; Woo, C.W.; Choy, P.C. \& O, K. 2005. Emerging issues in traditional Chinese medicine. Can. J. Physiol. Pharmacol. 83(4): 321 - 334.

Sodhi, N.S.; Koh, L.P.; Brook, B.W. \& Ng, P.K.L. 2004. Southeast Asian biodiversity: an impending disaster. Trends Ecol. Evol. 19(12): 654 - 660.

Sunandar, A.D.; Barus, S.P.; Kuswanda, W. \& Saputra, M.H. 2019. Vegetation Diversity and Conservation Implications on Habitat of Taxus (Taxus sumatrana Miq. De Laub) in Northern Sumatra. Proceedings of the International Conference on Natural Resources and Technology, Pp. $365-371$.

Tangjang, S.; Namsa, N.D.; Aran, C. \& Litin, A. 2011. An ethnobotanical survey of medicinal plants in the Eastern Himalayan zone of Arunachal Pradesh, India. J. Ethnopharmacol. 134(1): $18-25$. 
Tanvir, R.; Javeed, A. \& Bajwa, A.G. 2017. Endophyte bioprospecting in South Asian medicinal plants: an attractive resource for biopharmaceuticals. Appl. Microbiol. Biotechnol. 101(5): $1831-1844$.

Thapa, S. 2012. Medico-ethnobotany of Magar community in Salija VDC of Parbat district, central Nepal. Our Nat. 10(1): 176 - 190.

Thomas, P.; Sengdala, K.; Lamxay, V. \& Khou, E. 2007. New records of conifers in Cambodia and Laos. Edinburgh J. Bot. 64(1): 37 - 44.

Thomas, P. 2011. Taxus contorta. The IUCN Red List of Threatened Species 2011: e.T39147A10170545. http://dx.doi.org/10.2305/IUCN.UK.20112.RLTS.T39147A10170545.en.

Thomas, P. \& Farjon, A. 2011. Taxus wallichiana. The IUCN Red List of Threatened Species 2011: e.T46171879A9730085. http://dx.doi.org/10.2305/IUCN.UK.20112.RLTS.T46171879A9730085.en.

Thomas, P.; Liao, W. \& Yang, Y. 2013a. Amentotaxus assamica. The IUCN Red List of Threatened Species 2013: e.T34113A2846686. http://dx.doi.org/10.2305/IUCN.UK.20131.RLTS.T34113A2846686.en

Thomas, P.; Li, N. \& Christian, T. 2013b. Taxus chinensis. The IUCN Red List of Threatened Species 2013: e.T42548A2987120. http://dx.doi.org/10.2305/IUCN.UK.20131.RLTS.T42548A2987120.en.

Thomas, P. 2013. Amentotaxus formosana. The IUCN Red List of Threatened Species 2013: e.T31265A2802875. http://dx.doi.org/10.2305/IUCN.UK.20131.RLTS.T31265A2802875.en

Thomas, P. \& Yang, Y. 2013. Pseudotaxus chienii. The IUCN Red List of Threatened Species 2013: e.T32798A2823334. http://dx.doi.org/10.2305/IUCN.UK.20131.RLTS.T32798A2823334.en.

Thomas, P.; Gao, L. \& Phan, K.L. 2017. Amentotaxus yunnanensis. The IUCN Red List of Threatened Species 2017: e.T118076066A96812158. http://dx.doi.org/10.2305/ IUCN.UK.2017-2.RLTS.T118076066A96812158.en.

Tiwari, S.P. \& Chauhan, D.K. 2006. Gymnospermous biodiversity of Himalayas: Their economic importance and conservation. J. Econ. Taxon. Bot. 30(4): 803 - 809.

Uprety, Y.; Poudel, R.C.; Asselin, H.; Boon, E.K. \& Shrestha, K.K. 2011. Stakeholder perspectives on use, trade, and conservation of medicinal plants in the Rasuwa district of central Nepal. J. Mount. Sci. 8: $75-86$.

Wangyal, J.T. 2012. Ethnobotanical knowledge of local communities of Bumdeling wildlife sanctuary, Trashiyangtse, Bhutan. Indian J. Trad. Knowl. 11(3): 447 - 452.

Wani, M.C.; Taylor, H.L.; Wall, M.E.; Coggon, P. \& McPhail, A.T. 1971. Plant antitumor agents. VI. Isolation and structure of taxol, a novel antileukemic and antitumor agent from Taxus brevifolia. J. Am. Chem. Soc. 93(9): 2325 - 2327.

WHO [World Health Organization], 2001. General Guidelines for Methodologies on Research and Evaluation of Traditional Medicine. WHO, Geneva, Switzerland.

www.plantsofthewirldonlone.org

Xu, J.; Grumbine, R.E.; Shrestha, A.; Eriksson, M.; Yang, X.; Wang, Y.U.N.\& Wilkes, A. 2009. The melting Himalayas: cascading effects of climate change on water, biodiversity, and livelihoods. Conserv. Biol. 23: 520 - 530. 
Yang, H.R.; Hu, X.P.; Jiang, C.J.; Qi, J.; Wu, Y.C.; Li, W.; Zeng, Y.J.; Li, C.F. \& Liu, S.X. 2015. Diversity and antimicrobial activity of endophytic fungi isolated from Cephalotaxus bainanensis Li, a well-known medicinal plant in China. Lett. Appl. Microbiol. 61: 484 - 490.

Yang, Y.; Christian, T. \& Li, N. 2013a. Taxus mairei. The IUCN Red List of Threatened Species 2013: e.T191659A1991533. http://dx.doi.org/10.2305/IUCN.UK.20131.RLTS.T191659A1991533.en

Yang, Y.; Luscombe, D. \& Katsuki, T. 2013b. Cephalotaxus harringtonii. The IUCN Red List of Threatened Species 2013: e.T39589A2929537. http://dx.doi.org/10.2305/ IUCN.UK.2013-1.RLTS.T39589A2929537.en

Yang, Y. \& Liao, W. 2013a. Cephalotaxus hainanensis. The IUCN Red List of Threatened Species 2013: e.T34065A2842288. http://dx.doi.org/10.2305/IUCN.UK.20131.RLTS.T34065A2842288.en

Yang, Y. \& Liao, W. 2013b. Cephalotaxus lanceolata. The IUCN Red List of Threatened Species 2013: e.T32330A2815177. http://dx.doi.org/10.2305/IUCN.UK.20131.RLTS.T32330A2815177.en

Yang, Y. \& Luscombe, D. 2013a. Torreya fargesii. The IUCN Red List of Threatened Species 2013: e.T191877A2011625. https://dx.doi.org/10.2305/IUCN.UK.20131.RLTS.T191877A2011625.en

Yang, Y. \& Luscombe, D. 2013b. Torreya grandis. The IUCN Red List of Threatened Species 2013: e.T191881A2011932. https://dx.doi.org/10.2305/IUCN.UK.20131.RLTS.T191881A2011932.en.

Yang, Y. \& Luscombe, D. 2013c. Torreya jackii. The IUCN Red List of Threatened Species 2013: e.T32379A2816957. https://dx.doi.org/10.2305/IUCN.UK.20131.RLTS.T32379A2816957.en

Zhasa, N.N.; Hazarika, P. \& Tripathi, Y.C. 2015. Indigenous Knowledge on Utilization of plant Biodiversity for Treatment and Cure of diseases of Human beings in Nagaland, India: A case study. Intn. Res. J. Biol. Sci. 4(4): 89 - 106. 